\title{
DEMYSTIFYING CREATIVITY: AN ASSEMBLAGE PERSPECTIVE TOWARDS ARTISTIC CREATIVITY
}

\author{
Adina MANTA* \\ Department of Sociology, Faculty of Sociology and Social Work, University of Bucharest, \\ București 070709, Romania
}

Received 9 May 2017; accepted 13 March 2018

\begin{abstract}
Common understandings of creativity reduce it to a flash of insight or to a personal characteristic of a highly-gifted person. This paper develops an alternative way of understanding creativity departing from a series of interviews with local painters by conceptualizing creativity as a process of articulating and getting caught up in a "meshwork" of materials, places, spaces and social encounters. Using assemblage theoretical framework, my perspective examines how different elements (both human and non-human) are brought together in flows of connections. Looking at the art world this paper takes into account also the materiality of the creative process and inquiry into how the materiality of working materials (paint, coal, brushes etc.) and the materiality of the space affect and are affected in the creativity assemblage. As such, departing from an anthropocentric perspective on artistic creativity, that takes into consideration only the meanings attributed by people (especially the artist) to forms, social uses and trajectories of artistic objects.
\end{abstract}

Keywords: assemblage, creativity, flows, materiality, rhizome.

\section{Introduction}

Often, common stereotypes tend to link creativity to innovation, originality, spontaneous and solitary processes. Even though we tend to talk about creativity in one way or another on a daily basis ("creative work", "creative class", "creative city", "creative writing", "creative thinking", "creative personality" etc.) it remains an almost absent concept from the social sciences. As a taken for granted concept, creativity needs further investigations in order to gain deeper and more comprehensive account of it. Even though creativity has been seen as the muse, or as the "aha moment", or as a specific personality trait, or as a cognitive process, it still remains a "black box". In recent academic literature, creativity has been approached either from a psychological point of view (Glăveanu, 2010; Botella et al., 2013) or from a sociological perspective (Reuter, 2015). The latter stand of research includes discussions about creative products, creative industries, creativity institutions, creativity and art and so on. There is a

\footnotetext{
*Corresponding author. E-mail: adina.manta@sas.unibuc.ro
} 
focus on understanding the institutions of creativity, the creative economy and creativity industries (Florida, 2004; Hartley, 2005; Landry, 2000), the creativity of social action (Joas, 1990), creative society (Reimeris, 2016), creative city (Brzozowska, 2016), everyday creativity (Richards, 2010), art and creativity (Becker, 1984; O’Sullivan, 2006; Ingold, 2010; Juzefovič, 2016). Although these studies reveal creativity as a multifaceted phenomenon, only few of them address the issue of artistic creativity as a social process.

This paper approaches creativity not as a flash of insight/genius but as a process of articulating and getting caught up in a "meshwork" of materials, places, spaces and learning encounters. Also, I am mapping creativity as an assemblage, trying to understand how different elements are brought together in flows of connections. As such, I propose a deeper understanding of it in the context of art and art making by drawing upon a theoretical framework inspired by Gilles Deleuze, Félix Guattari, Bruno Latour and Tim Ingold. The main objective of this paper is to understand how the materiality of working materials (paint, coal, brushes, etc.) and the materiality of the space affects and is affected in the creativity assemblage and how is intertwined with flows generated by human actors. Drawing on conceptualizations of agency as relational and distributed (Latour, 2005), I look at how various things, materials, spaces, shapes, and bodies become entangled in the creation process. Thus, I conceptualize creativity as a socio-material process, an assemblage in which various human and non-human actors are involved. Although, as creativity was seen as the corner stone of art, I propose a deeper understanding of it in the context of art and art making. With this goal, this work explores artistic practices in order to cast a sociological light upon creativity and even if I refer to artists and art practices, the focus does not relay on addressing the issues of creativity in art but the issue of creativity as a social construct.

Drawing on interviews with local visual artists (especially painters) and observations inside the art studios, this article proposes a new conceptualization of creativity accounting it as a social dynamic process. In other words, investigating contemporary visual artists work practices and biographies, this article concentrates on mapping and tracing the world of creativity in order to portrait it as an assemblage.

The remainder of the paper is organized in 3 sections: The literature review section is devoted both to: Situating creativity in the social world - by exploring the social science perspective towards the problem of creativity, but also to: Situating art in the social world, section in which are presented social science theories regarding art practices and processes. The theoretical framework and methodology section presents the proposed research designed followed in the empirical process of this paper, followed by the results section which presents the main insights of the empirical process, tracing the flows of materiality and social flows in artists discourses and thus mapping the creativity assemblage. The final section of this paper summarizes the results of this work and draws conclusions.

\section{Literature review}

\subsection{Situating creativity in the social world}

Creativity is an almost absent concept from the social sciences. Monika E. Reuter's (2015) book Creativity - A Sociological Approach represents a great contribution to the developing 
field of sociology of creativity but also illustrates the challenges and opportunities in studying this concept. As Reuter (2015, p. 2) states, creativity is "a concept everybody uses, but that is difficult to define". In recent discussions about it, a controversial issue has been whether creativity can be understood in the framework of social sciences. According to Vlad Petre Glăveanu and Brady Wagoner (2015, p. vii), "Creativity as a construct is difficult to place in a sociological frame because it potentially refers to many things at once: people, processes, attitudes, beliefs, action orientations and so and so forth". Even though Glăveanu's statement approaches the challenges in studying creativity, I consider that the difficulty in assessing creativity from a social point of view also relies in the ambiguity of this black box concept. Latour (1999, p. 304) defines the black box as:

"the way scientific and technical work is made invisible by its own success. When a machine runs efficiently, when a matter of fact is settled, one need focusses only on its inputs and outputs and not on its internal complexity. Thus, paradoxically, the more science and technology succeed, the more opaque and obscure they become".

Thus, understanding creativity as a black box as in the case of scientifically work, creativity also becomes invisible by its own success, most of the time not needing to zoom in on the internal complexity of the process but only on the inputs and outputs.

Current research argues that creativity can be deciphered also as a social construct. In recent years, there has been a switch in the paradigm of studying creativity from an individualist point of view to a more social one. An important step was made by Glăveanu (2010) by introducing the cultural psychological paradigm that focuses on sociocultural dynamics of creative acts and builds his argument on a framework which incorporates three key elements: self, community, new and existing artefacts. This sociocultural perspective on creativity was also undertaken by Romina Cecilia Elisondo (2016) who argues that the creative ideas are the outcome of the interactions with other people and are culturally constructed and reconstructed through knowledge and producers. Situating creativity in the sociocultural perspective represents a step forward in understanding creativity not as a result or characteristic of an independent individual or the centre of the psychological experience but as a social process that does not exist outside of social relationships. However, I find the argument of the sociocultural perspective limitative and incomplete because of its understanding of the social only in terms of individuals, relations and interactions, thus ignoring from the argument elements such as objects, practices, social spaces which also compose the rhizomatic world of creativity. The classic perspectives in the literature on social are anthropocentric in which people inscribe meaning in the forms, the uses and trajectories of things. For example, from a Durkheimian (Durkheim, 1982) perspective a society orders the world of things on the pattern of the structure that prevails in the social world of its people. Jean Baudrillard (1988) portraits things as representation of ideological constructions of bourgeons capitalism society while Marcel Mauss (1966) approaches the way that the exchange of objects between groups builds relationships between humans. Georg Simmel concentrates on adornment of things (cited in Wolff, 1964) while Erving Goffman (1967) presents things as signs of social bounds. Moving from an anthropocentric perspective in understanding the social to an alternative approach in which things inscribe meaning (Appadurai, 2003; Brown, 2001) this paper draws on Latour's (2005, p. 5) defini- 
tion of the social not as a label but rather as "type of connection between things that are not themselves social". Creativity from a critical sociology point of view can also be studied as a matter made of associations of ties which are themselves non-social. I argue that a socio-materialist approach offers a more comprehensive understanding of creativity by looking at how things inscribe meaning in the artistic process. So, mapping the creativity assemblage implies identifying the flows between human but also non-human actors in order to decipher the internal complexity of creativity as a process.

In Lene Tanggaard (2013, p. 20) studies of the everyday life creativity is portrait as: "an everyday phenomenon resulting in continual process of 'making the world' highlighting the relationship between materials and ways of doing as starting points for creative processes". The making of the world, as Tanggaard (2013) states it, can be linked with Deleuze and Guttari (1988) concept of becoming:

"We are not in the world, we become with the world, we become by contemplating it. Everything is vision becoming. We become universe. Becoming animal, plant, molecular, becoming zero" (O'Sullivan 2006, p. 56).

From this perspective, my view is that creativity is more than just something static and more of a fluid process that is in a constant state of becoming through the connections between different flows, whether they are flows of materiality or flows of ideas. Furthermore, addressing the socio-materiality of creativity, Tanggaard (2013) assesses environments not only as conditions for creativity but also as components of it, illustrating from a dialectical point of view the encounter of materials and individuals in the process of creativity. The dialectical perspective undertaken by Tanggaard (2013) highlights the critique of Ingold (2010) towards the hylomorphic model of distinction between form and matter. According to Ingold (2010) the hylomorphic model is limitative because it does not capture the ontological relationships between processes and formations, flows and transformations of materials. Ingold's theory is extremely useful in deciphering creativity as an assemblage shading light on the complexity of social aggregates that describe this concept. By social aggregates I will undertake Latour (2005, p. 65) definition of the social not as "an association between entities which are in no way recognizable as being social in the ordinary manner, except during the brief moment when they are reshuffled together". In order to decipher creativity in the art practices of visual artists, we need to make a step forward in our journey through the literature and to have a quick stop in the art section of sociology.

\subsection{Situating art in the social world}

In this section, in order to reach the point in which art and creativity encounters Deleuze and Guattari I find it necessary to undertake the journey through social theories and approaches that illustrated art as more than an individual action, and to sketch a theoretical map for solving the puzzle of creativity. This section outlines some of the major approaches/theories from social sciences regarding mainly the problem of art and art practices.

From a sociological point of view, the main focus in art studies was on an institutional perspective of art production, reception and circulation (Gell, 1998). Pierre Bourdieu focused his analysis around social and economic power relations. Bourdieu's structuralist perspective 
on art was aimed at explaining the production and consumption of art and culture from an economic point of view:

"In the cultural market - and no doubt elsewhere - the matching of supply and demand is neither the simple effect of production imposing itself on consumption nor the effect of a conscious endeavour to serve the consumers' needs, but the result of the objective orchestration of two relatively independent logics, that of the field of production and that of the field of consumption" (1984, p. 230).

On the other hand, Alfred Gell (1998) had an animist perspective towards art and art objects and concentrated his argument around the network of relationships regarding the artworks. The anthropological theory of art proposed by Gell discussed it as a system of actions in which the social relations between objects were mediating the social agency, the art objects being those who had:

"semantic and or aesthetic properties that are used for presentational or representational purposes [...] sign vehicles, conveying meaning or they are objects made in order to provoke a culturally endorses aesthetic response" (1998, p. 6).

Despite, the innovative approach of Gell theory which positioned objects as having agency in the artistic process, a key limitation of his work lies in the anthropocentric perspective, favouring the human action in his argument, non-human agents having only "second-class" agency (Fox, 2015). Also, in Nick Fox's critique of Gell theory, the lack of temporal change in the agency of elements is underlined. Also, another critique is the limitative character of the theory which downplays other possible factors that might affect the process of creation (Fox, 2015). I stand by the critique of Fox, and I also consider that the problem with this approach is that the art process of creation is regarded as static. Also, the artist is situated as the main agent, the objects are positioned as only borrowing agency from the artist, they lie only in the background of creation.

The art world was also theorized by Howard S. Becker (1984) which borrowed Herbert Blumer's concept of "joint action" and used it in analysing the networks of art and art making. The main plus of Becker's theory relies in his view of the art world as a collective action in which the art products are seen as a result of a network of coordinated activities carried on by different people and not only the artist. In Becker's view, understanding art implies understanding the networks of people involved in the process of art making and not only the artist. Also, the art product in Becker's theory is the result of a process in which there are involved artists but also supporting personal. According to his view, the network that forms the art world has in its centre the artist and around him gravitates the supporting personal that is essential to the final outcome: "The artist thus works in the centre of a network of cooperating people, all of whose work is essential to the final outcome" (Becker, 1984, p. 25). Although I agree with Becker up to a point, I cannot accept his overriding definition of the art world as a network of cooperating people (human agents) but rather as an assemblage of human and non-human actors and the links and flows between them. Firstly, I find Becker's definition of the art world limitative, losing sight of non-human agents such as things, materials or social space that are also involved in the art process and practices. Understanding the art world in Becker's terms implies an anthropocentric view of the art process and of creativity. Secondly, Becker in debating the art as a collective action understands the concept of action 
as rational and conscious. One of Becker's research question stated in the introduction of his work Art Worlds is: "Who makes what choices about a work and with what result?" (1984, p. xviii). The main characters/nodes of the network remain the artist and the supporting personal, while in an actor-network perspective the action: "is not done under the full control of consciousness, action should rather be felt as a node, a knot and a conglomerate of many surprising sets of agencies that have to be slowly untangled" (Latour, 2005, p. 45). Also, even if I agree with Becker that art is composed of collective actions, in this paper collective refers not only at actions between people but also social forces, materiality and objects that woven together and form the art world as an assemblage. Thirdly, Becker gives a privileged place to the artist in the network of the art world, situating him in the central node/point. The major drawback of this approach is that Becker's network is hierarchical and by default speaks about power relationships. In my view the artistic creativity assemblage follows Deleuze and Guattari principal of rhizome which is a system without a centre and "has no beginning or end, it is always in the middle, between things, interbeing, intermezzo" (Shields \& Vallee, 2012, p. 155). Understanding the art world as rhizomatic implies understanding the art practices as Simon O'Sullivan (2006, p. 32) illustrates: "a fluid and dynamic system always in connection with a number of different regimes and registers". All in all, Becker's view of the art world is a step forward in the decentralization of the art process and in portraying art and creativity as an assemblage.

In my theoretical journey of sketching artistic creativity as an assemblage it is required a better understanding of the concepts of object and agency. If for Latour the object is an important part of the actor-network representing a placeholder that has agency, Ingold (2010) criticizes Latour by making the distinction between objects and things ${ }^{1}$ and between agency and life. The main critique of Ingold towards Latour actor-network theory is that Latour by focusing his theory on objects tends to cut them off from the flow that give them life and also: "to render the life of things as the agency of the objects is to effect a double reduction, of things to objects and to life to agency" (Ingold, 2010, p. 7). Also, approaching Ingold's argument, Latour concept of network is deconstructed and replaced with the concept of meshwork. I consider that the meshwork represents a more phenomenological approach of the network. According to Ingold (2010) in a meshwork the key is to follow pathways or trajectories not connections but rather lines along which things continually come into being. Following the author's argument, the artwork and the process of art creation is not so much an intervention on form and mater but rather a process of combing and redirecting the flow of things in the anticipation of what might emerge ${ }^{2}$. So, understanding the world in Ingold's framework implies visualizing an environment without objects which is a world of materials and matter in flux. This fluid and dynamic perspective of Ingold upon an environment

\footnotetext{
${ }^{1}$ Ingold portraits the concept of things by drawing on Martin Heidegger's essay "The Thing” (2001).

${ }^{2}$ For example, if thinking about a painter and the process of painting, according to Ingold the painter: "is in the business not so much of imposing form on matter as of bringing together diverse materials and combining and redirecting their flow in the anticipation of what might emerge [...] the artist joins and follows the forces and flows of material that bring the form of the work into being" (Ingold, 2010, pp. 9, 11). So, I consider that observing a painter working is essentially to follow the movement of the body, the process of combining the materials (the oil painting, the acrylics), the movement of applying the paint on the canvas and how the canvas comes to life in this process by partaking the essence of the other movements of matter, body, things, all woven together.
} 
without objects represents a more embodied approach to the concept of assemblage which will be traced in my analyses on visual artists' work practices and biographies in order to trace the world of creativity.

The main focus of this paper is to address one scarcely investigated domain from social science, creativity. Based on the approaches presented in section: Situating creativity in the social world and section Situating art in the social world, the purpose of this paper is to open new directions in studying taken for granted concepts, black boxes of human experience, understanding them beyond the anthropocentric perspective in which the social is reduced only to human actors. The fundamental statements that guided my empirical work are derived both from Latour's (2005, p. 5) definition of the social not as a label but rather as "type of connection between things that are not themselves social" and also from Deleuze and Guattari (1988) conceptual apparatus of the assemblage. The theoretical innovation of this paper consists in combining the two theoretical apparatus, thus proposing a novel approach to how creativity as a social phenomenon comes into being by dislocating the centrality of the human actors in the processes of becoming. Looking at creativity through the lens of assemblage, provides a theoretical framework for analysing artistic practices as processes of articulating and getting caught up in a "meshwork" of materials, places, spaces and social encounters, without having the artist as the central node in the becoming of an art work.

\section{Theoretical framework and methodology}

The research design used for gathering my data, enrols in the phenomenological studies and is based on methodological bricolage. It can be summed up in the following phases:

- definition of a conceptual model (the theoretical framework of the assemblage resulted from Latour model of actor-network theory combined with Deleuze conceptual definition of assemblage and Ingold perspective of materiality);

- establishment of a set of dimensions of analysis (the materialistic dimension of creativity and the social one in terms of humans, ideas, encounters and interactions).

The empirical work was based on direct observation in 4 visual artist's studio and 11 life story interviews with contemporary visual artists from Bucharest, Romania. The fieldwork was conducted between October and March 2017. Having an opportunity sampling, I conducted life story interviews with 11 visual artists from Bucharest. The life-story interviews, focused on their life trajectories and artistic evolution in order to collect narratives about what meant for them to be an artist and how creativity and the artistic creation was being shaped in their discourse. From deductive analysis on the interviews I could trace how artists' narratives portrait creativity more as a process of articulating and getting caught up in a network of materials, places. Also, their narratives about their life trajectories outlined what has become the central argument of my research: the transition from being an artist to becoming an artist, the never ending process of becoming which sums up the assemblage of creativity. For the sake of a methodological bricolage, I mixed the results from life story interviews with results from a participant observation conducted in 4 artist's studios.

Another qualitative technique used for gathering the data was field recording in order to capture in an audio format the process of creating an art work. This technique allowed me to 
have a better representation of the creation process as a rhizome, as a network without centre, in which the nodal points are connected to one another in a non-hierarchical manner; illustrating the process of creation without having as a referential point the artist. To be more precise I left the recorder near one artist easel and I recorded the sound of different actors that interact in the moment of creation. I tried to record the sound of the materiality of the working materials (coal, paint, brushes, canvas etc.), the sound of the artist, the sound of the studio.

\section{Tracing the world of artictic creativity}

Entering an art gallery, we stop for a moment in front of a painting (see Fig. 1).

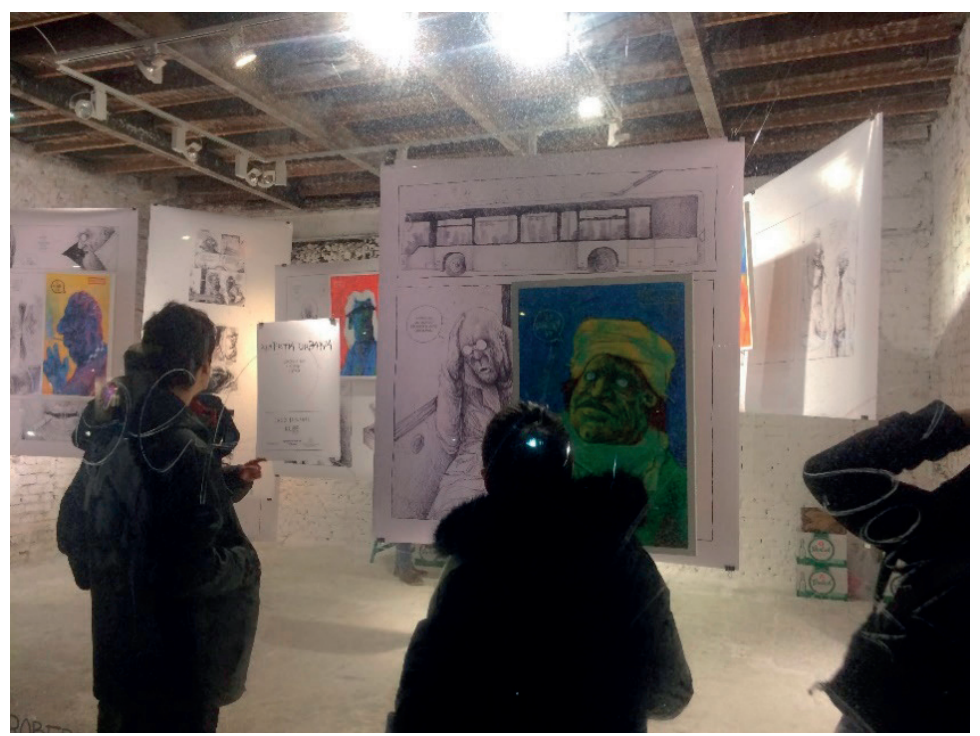

Figure 1. Art work by local artist Robert Obert from one exhibition attended by the author during the empirical phase of this paper (source: created by author)

But, one may ask, what is the story of this painting, what narratives the painting creates, what narratives has between the brush strokes, between the paint and the canvas, between the artist and the ideas and emotions that led to this art object. Taking a step back, the painting tells the artist story and is an artefact of all the flows and connections that came into being and led to this very moment in present, standing in front of it in an art gallery. The painting is just a small part of the bigger picture of artistic creativity and only the tip of the iceberg in tracing the complex mechanisms that led to the process of creating it. A dynamic understanding of creativity reveals the process of painting of this art work as just a small event from the continuing process of becoming an artist.

This paper represents an attempt to capture the flows between things, materiality, social space and human actors, mapping the nodes and flows of creativity. Following artists discourse about their life trajectories and artistic evolution, creativity reveals more as a dynamic process and less as a moment in time, a revelation or the centre of the psychological experience. Thus, understanding creativity as a process implies understanding the process of becoming an art- 
ist and mapping the human and non-human elements that compose an assemblage in which creativity emerges. Not least, creativity is described in the artists' discourse as consisting of moments of becoming, meetings of forces and flows, and a constant interconnecting of different elements that constitute the creativity assemblage. Next, I am going to trace the different flows of materiality and social flows and how they assemble in the artistic process.

\subsection{Flows of materiality (objects/things, working materials, art studio)}

The anthropocentric perspective on artistic creativity is limited only to the meanings attributed by people (especially the artist) to forms, social uses and trajectories of artistic objects. This leaves aside the fact that things may inscribe meaning in the artist process. Undertaking a socio-materialistic approach to the creativity assemblage, I will describe in the followings the flows of materiality set in motion by artist's working materials and the art studio as a physical and social space.

\subsection{The working materials}

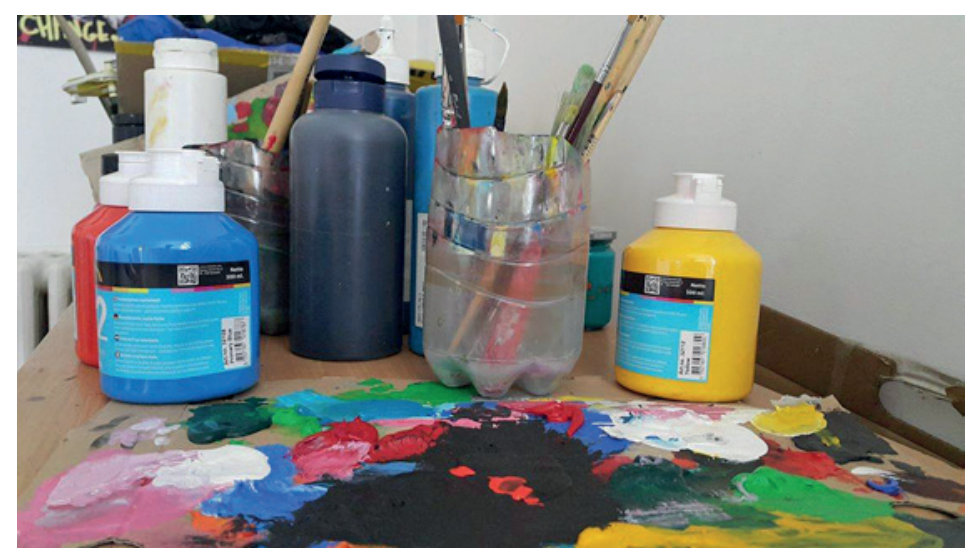

Figure 2. Artist's working materials (source: photo was taken by author during the field work in one of the painters art studio)

Tracing the act of creation of an art work implies tracing creativity through processes of formation and transformations. Departing from the model of matter versus form, I look at the matter in movement through tracing the paths of form-generation in the creativity process. In the act of painting one traces the transition from objects to things and see how the working materials such as oils, acrylics, coals, canvas, papers, crayons (see Fig. 2), all come to life. The artist does not impose form on matter but the matter through movement becomes part of the creativity assemblage, generating flows of affects. The artist brings together different elements and materials but also directs flows in the anticipation of what might emerge. The physic properties of each element that comes into being in the process of creation are mixed together and are mutually reinforcing each other generating flows of affects. Objects such as the canvas, the oils, the acrylics, the brushes, all have different properties that once set in motion through the act of painting become things and part of the creativity assemblage generating flows of materiality in the act of creation. For example, the process of preparing 
the canvas for painting implies mixing together different elements, combining different matters. The painter can mix chalk powder with bone paste and honey to make a primer that will be applied on the canvas in order to obtain a certain texture of the canvas. Following this process of formation and transformation of the canvas by mixing and combining matter leads to tracing the world of materials, the fluxes of matter that offers a glimpse of the environment without objects ${ }^{3}$ of the artistic world as part of the creativity assemblage: "In order to obtain a very soft canvas I had to mix honey and food gelatine and to apply it on the canvas. I needed a texture that would let me draw certain lines, very soft and clean lines. It was a must that the texture of the canvas to let the paint slide smoothly" (L.).

For painters there is no such thing as just a canvas. Each canvas through its materiality generates and responds to different needs. The cotton canvas compared with the linen, will mix differently with the paint due to its texture, density and how the cloth was weaved. After preparation, the materiality of the canvas will mix with the materiality of the paint, with its pigments, texture and so on. The pathways of this fluxes of matter unfolds how the creativity assemblage comes into being: "It is a very big difference between cotton canvas and linen. The cotton canvas is more rough due to how was weaved, while the linen is more delicate and soft and the paint slides more softly on the canvas" (J.). Choosing a canvas implies thinking about creativity and the creation process in terms of materiality: a canvas is translated by the artist in the process of preparation and mixing different solutions in order to gain a certain texture, a canvas anticipates what sort of paint will be used in the process of painting, what pigments mix better with a certain kind of texture, what kind of brushes fit the texture of the canvas and so on.

After the canvas is set on the easel another process of mixing can be traced, the mixing of colour on the drawing palette and the mixing of colours between them on the canvas and with the canvas. This process of mixing different elements in the process of painting illustrates the movement of flows that generate affects as the work of art is being shaped. Mixing colours with water or turpentine in order to reach a certain colour shade represents also a part of the process of the becoming of an art work: "I love to paint with oil, it is so easy to shape the colour and the line. It mixes really nice with other colours but also it is very pretentious due to the fact that you need to control it [...] I mean with oil you should be really careful how much turpentine you add so you won't ruin the colour, the pigment. Also, you need to control its texture to be thick enough to lie perfectly on the canvas" (G.). Also, applying the paint on the canvas reveals the effect of the paint brush; different shapes, different sizes, different fabric, paint brushes through their materiality enter the flows of transformation that shape the final outcome (the art work). A simple line from the painting represents the results of mixing matters and generating flows of transformation that are directed by the artist in anticipation of what might emerge. Also, a line, a shape, a colour stain, all represent the outcome of the process of formation and transformation of materiality which underline the becoming of a distinctive art work. Each possible trajectory of intertwining the flows of matter generate a possible outcome (a possible art work) which is different in itself ${ }^{4}$.

\footnotetext{
${ }^{3}$ Ingold, departing from Deleuze and Guattari concept of body without organs, conceptualizes "the environment without objects": "is not a material world but a world of materials, of matter in flux" (Ingold, 2010, p. 8).

${ }^{4}$ Following Deleuze theoretical framework about difference and repetition where "a difference which is in and for itself, not difference resulting from anything external, but self-related, and therefore simple difference” (Hughes, 2009, p. 41).
} 


\subsection{The art studio}

The art studio (see Fig. 3) is more than a container for creativity and creation, it becomes part of the creativity assemblage. Thus, it becomes more than an environment that creates conditions for creation, through its materiality generating flows of connections between ideas. As contemporary visual artists' work practices involve sites and modes of production, the materiality of the space becomes part of the creation process: "In my first art studio I really felt I was starting to grow and to mature as an artist. It was the place where I started to build my career. Those empty walls that could hardly wait to exhibit my works. Those big windows that gave me the light that I needed" (J.).

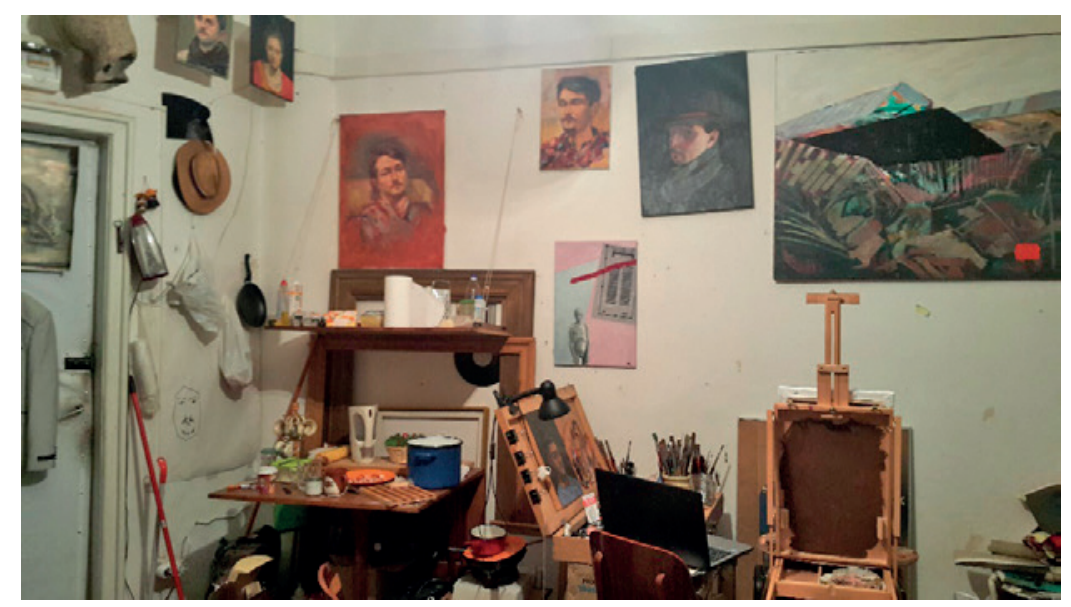

Figure 3. Artist studio (source: photo was taken by author during the field work).

In these spaces the artist initiates creatively the experiencing of the space not only as an object, but also as a thing that is part of the artistic creation process. Not only a work place or physical container for creation and contemplation, the studio reveals the complex relationship between materials and forces in the process of art making. The art studio can also be deciphered as a mediator ${ }^{5}$ transforming meanings of elements. For example, a window from an art studio becomes part of the creativity assemblage since it is the main source of light. The window as the main source of light in an art studio becomes the element that creates dynamicity and movements, the artist reconfiguring the space according to were the window is situated. In the case of an art studio, the window is not just an object with the functionality of observing what happens outside or to provide day-light in the house, the window becomes a thing which influence the artistic environment and the movement of the objects from this environment. It sets in motion flows of materiality and becomes also part of the art work. Also, the window becomes the link between inside (the studio) and outside, connecting two worlds that frame the environment of creation. Opening the window, new actors enter the site of creation and combine with elements already in the studio, generating flows of ideas:

\footnotetext{
5 The term is used according to Latour's definition (2005, p. 39): “(mediator) transform, translate, distort and modify the meaning or the elements they are supposed to carry".
} 
"One day I came to the studio and I was in no mood for working. I remember it was spring time and I opened the window and sat on the couch smoking a cigarette. I closed my eyes and I felt the smell of spring mixing with the smell of the cigar and from there this painting that you see on that wall was born" (O.). Also, the reality seen by the artist through the window is shaped by the actors already existing in the studio, sensorial flows such different smells from the studio that merge with the visual images the artists get by looking out the window and thus new flows of ideas are generated.

The light is a very important element becoming part of the painting process, the colours, the shapes, the drawings, the lines, all depending on the light. Tracing the light, we trace the flows of transformation and creation of a painting. "Chasing" the light implies moving the easel all the time in order to capture that "perfect light" in the painting. The light, the window, the easel, the oils, the canvas, the brushes all woven together generating flows that configure the final art work. The moment of creation represents a blend between the life from every node and flow of the assemblage. The physical space itself is more than a background for artistic practices and intervenes in the act of creation, generating connections between nodes of the assemblage: "One of my first art studio it was really rough. The paint was coming down from the walls, the smell of an old house, the old wood from the windows. It was perfect even if it was really damaged. One wall was even damaged than the others. But it was perfect to get me in the mood for creating. It was exactly what I need to look at while I was painting. It helped me a lot to finish my project that was in the same note as that damaged space" (R.). The art studio represents also a place for dialog between artist and the artistic community, between artist and his own experiences, feelings, between matter and form, between materiality and space, between artist and all of the above. It is more than just a workplace; it is what meshes together all the threads of life that are part of the creativity assemblage.

\subsection{The art world}

Understanding creativity, we trace back to understanding the art world in which the artistic creation and the artist are situated. When discussing about artists we have to situate them in an art world where the public, the art critics, the gallerist, the art buyers, the art trends are links in the creativity assemblage. The artistic creation is not a process that happens in a vacuum, it is a process that happens in an art world, where the artist is aware of the art trends, of who is going to be interested in his works, of where he can exhibit, and what are the possible trajectories of his artwork. The art world in which the artist defines himself and becomes an artist is made of conventions, standardized ways of doing and talking about things, standardized ways of interacting, which are taken for granted and influence how the creativity assemblage emerges.

Following the assemblage of creativity leads us also to the discursive aspects of the art world. The art world itself creates a way of talking about art and creativity, a way of constituting knowledge. This specialized language specific to the art world can be understand as a Foucauldian discourse, as a "complex network of relationships between individuals, texts, ideas, and institutions, with each 'node' impacting, to varying degrees, on other nodes" (Leckie, Given, \& Buschman, 2010, p. 65). The fluxes between texts, ideas, individuals intertwine together and generate flows of affects that are part of the creativity rhizome. The artist 
creates his art works by taking into account the current and the past artistic trends: "My art studio is full of art albums. As an artist you should know a little bit of art history, you should know how to recognize a certain painting as part of an art trend. Also, I like to go to annual biennales to see what is "hot" nowadays, to see what artists from all over the world are doing" (R.). All the information and ways of talking about art resulted from different encounters between the artist and art specialists (art curators, art professors, art books, other artists, art public etc.) generate a way of doing things, a way to relate to art and creativity, a way of talking about art, a way of creating but also a way of defining himself or herself as an artist.

The becoming of an artist and implicitly of an art work is also the result of this discourse of the art world which can be traced in the lines and the brush strokes of a painting. The art world is part of the artistic artefacts, and by talking about them they become (or not) art objects: "I remember when I came in Bucharest as a student at the art university. I was used to drawing realists but all my professors where talking about my paintings as if there were simple reproductions. It was very frustrating for me in my first year of college to be perceived by everyone as a good painter for reproductions. They said that my works were not works of art and that maybe someday I could be called an artist. The sad story is that after you finish the art school you will meet the art curator and art gallerist. Good luck with that" (T.).

What is and what is not an art work? Who is and who is not an artist? All of these are questions that highlights the existence of a discourse about art and artistic value which generates flows of affect upon the creativity assemblage. The art gatekeepers such as art critic, art professors, gallerist constitute the formal art world that generates patterns of recognition of what means to be an artists and what is an art work. The artists, entering this formal art work by attending art schools, art shows, art exhibits, learn how to talk, how to see, how to dress, how to interact, how to think, "as an artist", unravelling the norms and modes of doing and being an "artist": "The collage period was the best. I stayed in the collage hostel and it was the best life. Only then did I learn to have fun. I went to art exhibits with my colleagues, we got drunk, we criticized the works of others, we have debates until late at night about the artistic trends and concepts. Only at college hearing how the teachers talk, how they pose the problem, how they talk about an exhibition I developed and I started thinking and talking like them. My professors were persons that I admired and wanted to be like them one day" (L.).

The art world in terms of ideas, art gatekeepers, art institutions is part of the artistic creativity assemblage. This are not just separate flows from the assemblage but they are interconnected with other flows such as the materiality ones and shape what will configure the creativity rhizome.

\section{Conclusions, or assembling the flows}

Creativity is an almost absent concept from the social sciences. It was the main purpose of this paper to draw attention upon creativity as a taken for granted concept in social sciences, and to propose a novel definition of it from a sociological stand by combining the theoretical apparatus of Deleuze and Guattari (1988) assemblage and Latour (2005) definition of the social. Thus, this paper illustrates creativity as a result of flows of affects between human actors, materials, objects, ideas etc. that woven together and come into being by dislocating the 
centrality of the human actors in the processes of creation. Creativity seen as an assemblage in which we can trace both human and non-human elements represents an attempt of understanding this taken for granted concept not from an anthropocentric perspective in which the artist imposes form on matter but from a more dynamic perspective in which each and every element come into being and shapes the becomings of creativity.

Summing up the results, it can be concluded that the moment of art making, of painting or drawing, does not start in the moment that the artist picks up the brush. Art making implies the interweaving of the different flows. It is a process that starts long before setting the canvas on the easel. All the encounters, all the connections between flows of information, flows of matter, flows of materiality, space, objects, every thread of life is made visible in the act of painting. Every single act or gesture made by the artist in the process of painting reveals how the flows of materiality and the social flows emerge and connect to each other. A line from the painting caries all the information the artist accumulated over time: all the information about the materiality of paint, of the canvas, of the brushes, about art styles, technics, art trends. Is a representation of all the encounters between the artist, the art world, the social world that comes together and are reflected on that particular moment when the artists set himself/herself in front of the easel and puts the brush on the canvas. Creativity is not only about intrinsic personality traits, it is a social construct, as Latour (2005, p. 5) states, a type of connection between things that are not themselves social. Using the conceptual framework of assemblage has broadened my empirical perspective accounting for creativity both in human actors and also non-human actors term. From artists' narratives creativity was shaped also in terms of physical and social spaces that stimulated ideas, different encounters, discourses about art, the objects that surrounds the artists in his everyday life, environmental aspects such as light and darkness, the art community.

From the research that has been carried out it is possible to conclude that artistic creativity is about the dynamics of the social world, it is a continues process of untangling, transforming and discovering the threads of life that come to be represented on a piece of paper or on the canvas. As Deleuze and Guattari (1988) argue that the whole world can be understand in terms of becoming.

Using the conceptual apparatus of Deleuze and Guattari (1988) of the rhizome, the art world presents itself as rhizomatic, all the art works connecting to every other element of this rhizome. An art work can be seen as more than an art object and more as a bundle of effects that affect its beholders. Through a theoretical bricolage by mixing Deleuze and Guattari (1988) definition and theoretical stand of assemblages, Latour (2005) perspective on the social, Ingold (2010) input on materiality and the social and Becker (1984) approach towards art world led not only to removing the artist from the centre of the art network but also making the invisible visible. Tracing creativity from a socio-materialistic perspective involved looking at a taken for granted concept (creativity) and situating it in an art world (Becker, 1984) from assemblage perspective (Deleuze \& Guattari, 1988) in which objects and spaces became also actors in this meshwork (Latour, 2005; Ingold, 2010) of artistic creativity. 
Demystifying creativity implies looking through a critical lens at a black box concept that even if it's part of our daily routine remains a taken for granted part of our social life. Understanding creativity not as the personality trait but more as a mesh of flows between elements that are themselves perceived as non-social and human actors sketches the rhizome of creativity. The canvas, the paint, the light, the art studio, the artist, the art critics, art professors, art gallerist, art books all come and mix together generating flows of affects.

Creativity as assemblage has been scarcely investigated but the literature is growing, revelling exciting ways of understanding how to look at what we already think we know.

\section{Acknowledgements}

Fruitful discussions with Professor Laura Grünberg and Professor Lazăr Vlăsceanu and their valuable feedback are gratefully acknowledged. Also, the author would like to thank her colleagues Dr Alexandra Ciocănel and Dr Istrate Andrada for their many useful comments and discussions on the topic. The author would also like to extend her thanks to Robert Obert (visual artist) for his support in entering the artists' studios.

Last but not least the author would like to acknowledge the valuable comments and suggestions of the reviewers, which have improved the quality of this paper.

\section{References}

Appadurai, A. (Ed.). (2003). The social life of things: Commodities in cultural perspective. Cambridge: Cambridge University Press.

Baudrillard, J. (1988). Selected writings. M. Poster (Ed.). Stanford: Stanford University Press.

Becker, H. S. (1984). Art worlds. Berkeley, Los Angeles, London: University of California Press, Ltd.

Botella, M., Glaveanu, V., Zenasni, F., Storme, M., Myszkowski, N., Wolff, M., \& Lubart, T. (2013). How artists create: Creative process and multivariate factors. Learning and Individual Differences, 26, 161-170. https://doi.org/10.1016/j.lindif.2013.02.008

Bourdieu, P. (1984). Distinction: A social critique of the judgement of taste. Harvard, Massachusetts: Harvard University Press.

Brown, B. (2001). Thing theory. Critical Inquiry, 28(1), 1-22. https://doi.org/10.1086/449030

Brzozowska, B. (2016). "Creative city" as a brand - The case of Łódź. Creativity Studies, 9(1), 3-14. https://doi.org/10.3846/23450479.2015.1112312

Deleuze, G., \& Guattari, F. (1988). A Thousand plateaus: Capitalism and schizophrenia. London: The Athlone Press Ltd.

Durkheim, E. (1982). The Rules of sociological method. S. Lukes, (Ed.). New York, London, Toronto, Sydney: The Free Press. https://doi.org/10.1007/978-1-349-16939-9

Elisondo, R. (2016). Creativity is always a social process. Creativity: Theories - Research - Applications, 3(2), 194-210. https://doi.org/10.1515/ctra-2016-0013

Florida, R. (2004). The rise of the creative class. New York: Basic Books.

Fox, N. (2015). Creativity, anti-humanism and the "New Sociology of Art". Journal of Sociology, 51(3), 522-536. https://doi.org/10.1177/1440783313498947 
Gell, A. (1998). Art and agency: An anthropological theory. Oxford: Oxford University Press.

Glăveanu, V. P. (2010). Paradigms in the study of creativity: Introducing the perspective of cultural psychology. New Ideas in Psychology, 28(1), 79-93. https://doi.org/10.1016/j.newideapsych.2009.07.007

Glăveanu, V., \& Wagoner, B. (2015). Series editors' foreword: Socializing creativity. In Reuter, M. E., Creativity - a sociological approach (pp. vi-viii). V. Glăveanu, B. Wagoner (Series Eds.). Series: Palgrave Studies in Creativity and Culture. New York: Palgrave Macmillan.

Goffman, E. (1967). Interaction ritual: Essays in face to face behavior. Chicago: Aldine Publishing Company.

Hartley, J. (Ed.). (2005). Creative industries. Oxford: Blackwell Publishing Ltd.

Heidegger, M. (2001). The thing. In Poetry, language, thought (pp. 161-184). Series: Harper Perennial Modern Thought. London: Perennial Classics.

Hughes, J. (2009). Deleuze's difference and repetition: A reader's guide. Series: Reader's Guides. Trowbridge: Cromwell Press Ltd.

Ingold, T. (2010). Bringing things to life: Creative entanglements in a world of materials. Working Paper No. 15. NCRM Working Paper Series. Retrieved from http://eprints.ncrm.ac.uk/1306/1/0510_creative_entanglements.pdf

Joas, H. (1990). The Creativity of action and the intersubjectivity of reason: Mead's pragmatism and social theory. Transactions of the Charles S. Peirce Society, 26(2), 165-194.

Juzefovič, A. (2016). Creative transformations in visual arts of early French modernism: Treatment of nude body. Creativity Studies, 9(1), 25-41. https://doi.org/10.3846/23450479.2015.1112854

Landry, Ch. (2000). The creative city: A toolkit for urban innovators. London: Earthscan.

Latour, B. (1999). Pandora's hope: Essays on the reality of science studies. Harvard University Press: Cambridge, Massachusetts, London.

Latour, B. (2005). Reassembling the social: An introduction to actor-network-theory. Oxford: Oxford University Press.

Leckie, G. J., Given, L. M., \& Buschman, J. E. (Eds.). (2010). Critical theory for library and information science: Exploring the social from across the disciplines. Santa Barbara, Denver, Oxford: ABC-CLIO, LLC.

Mauss, M. (1966). The gift: Forms and functions of exchange in archaic societies. London: Cohen \& West Ltd.

O'Sullivan, S. (2006). Art Encounters Deleuze and Guattari: Thought beyond representation. New York: Palgrave Macmillan. https://doi.org/10.1057/9780230512436

Reimeris, R. (2016). Theoretical features of the creative society. Creativity Studies, 9(1): 15-24. https://doi.org/10.3846/23450479.2015.1088902

Reuter, M. E. (2015). Creativity - A sociological approach. V. Glăveanu, \& B. Wagoner (Series Eds.). Series: Palgrave Studies in Creativity and Culture. New York: Palgrave Macmillan. https://doi.org/10.1057/9781137531223

Richards, R. (2010). Everyday creativity: Process and way of life - four key issues. In J. C. Kaufman, \& R. J. Sternberg (Eds.), The Cambridge handbook of creativity (pp. 189-215). Cambridge: Cambridge University Press. https://doi.org/10.1017/CBO9780511763205.013

Shields, R., \& Vallee, M. (Eds.). (2012). Demystifying Deleuze: An introductory assemblage of crucial concepts. Ottawa: Red Quill Books.

Tanggaard, L. (2013). The sociomateriality of creativity in everyday life. Culture \& Psychology, 19(1), 20-32. https://doi.org/10.1177/1354067X12464987

Wolff, K. H. (Ed.). (1964). The sociology of Georg Simmel. Glencoe, IL: The Free Press. 


\title{
KŪRYBIŠKUMO DEMISTIFIKAVIMAS: KOMPLEKSINĖ PERSPEKTYVA MENINIO KÜRYBIŠKUMO LINK
}

\begin{abstract}
Adina MANTA
Santrauka

Bendrasis kūrybiškumo supratimas redukuoja ji iki įžvalgos plykstelèjimo ar gabaus asmens asmeninès charakteristikos. Šiame straipsnyje plètojamas alternatyvus kūrybiškumo supratimo būdas, nukrypstantis nuo daugybès interviu su vietos tapytojais, konceptualizuojančiais kūrybiškumą kaip artikuliavimo procesą bei įstrigdančiais jị medžiagų, vietų, erdvių ir socialinių susitikimų „tinkle“. Pasitelkdama kompleksinį teorinị pagrindą, straipsnio autore iš savosios perspektyvos tyrinejja, kaip skirtingi elementai (tiek žmogiškieji, tiek nežmogiškieji) suvedami draugèn ị sąryšių srautus. Žvelgiant ị meno pasaulị, šiame straipsnyje taip pat skiriama dèmesio kūrybinio proceso materialumui ir apklausai, siekiant išsiaiškinti, kaip medžiagos, su kuriomis dirbama (dažai, anglis, teptukai, etc.), bei erdvès materialumas daro įtaką ir yra veikiami kūrybiškumui būdingo kompleksiškumo. Taip atsiplěšiama nuo menini kūrybiškumą vertinančios antropocentrinès perspektyvos, atsižvelgiančios vien tik ¡̇ žmonių (ypač menininkų) meno objektų formoms, socialinèms reikmėms ir trajektorijoms priskirtas reikšmes.
\end{abstract}

Reikšminiai žodžiai: kompleksiškumas, kūrybiškumas, srautai, materialumas, rizoma. 